BMJ Open

Sport \&

Exercise

Medicine

\title{
Is it necessary to adjust current creatine kinase reference ranges to reflect levels found in professional footballers?
}

\author{
Jamie Mahmutyazicioglu, ${ }^{1}$ Julian Nash, ${ }^{2}$ Andrew Cleves, ${ }^{1}$ Len Nokes ${ }^{1}$
}

To cite: Mahmutyazicioglu J, Nash J, Cleves A, et al. Is it necessary to adjust current creatine kinase reference ranges to reflect levels found in professional footballers? BMJ Open Sport \& Exercise Medicine 2018;4:e000282. doi:10.1136/ bmjsem-2017-000282

Accepted 3 November 2017
CrossMark

${ }^{1}$ Engineering Department, Cardiff University, Cardiff, UK ${ }^{2}$ Rheumatology Department, Morriston Hospital, Swansea, UK

Correspondence to Dr Len Nokes; Nokes@cardiff. ac.uk

\section{ABSTRACT}

Objective We aimed to explore the validity of applying current reference ranges of the enzyme creatine kinase (CK) when analysing the medical status of professional footballers and to offer a more functional CK reference range for professional footballers.

Methods A sample of 27 professional male footballers competing in The Football League Championship was analysed. The single sample Wilcoxon signed-rank test was used to compare the CK distribution of the study group with that of a control group of military personnel reported in the literature.

Results The median values for study group and the published control group were $284 \mathrm{U} / \mathrm{L}$ and $124 \mathrm{U} / \mathrm{L}$, respectively $(\mathrm{P}<0.001)$ suggesting that the average $\mathrm{CK}$ activity of professional footballers is higher than that of the normal healthy military population.

Conclusion Ethnicity, sex, age and physical exercise are factors that likely influence CK levels among various populations. From our analysis, we recommend a new $95 \%$ reference interval of $64.9 \mathrm{U} / \mathrm{L}$ to $1971.7 \mathrm{U} / \mathrm{L}$ for professional footballers.

\section{INTRODUCTION}

Creatine kinase (CK) is the key enzyme responsible for the catalysation of the interconversion of creatine phosphate and ATP in the human body, ${ }^{1}$ both of which are vital for a cell to metabolise healthily. ${ }^{2}$ However, studies suggest that high levels of CK present in the body can be a strong indicator of serious health issues such as myocardial infarctions and muscular dystrophy. ${ }^{3}$

CK levels in professional athletes are naturally higher than in the average person; however, a clear explanation for this difference is yet to be determined. ${ }^{4}$

Reference intervals of average levels of CK in the body for the general population can be found based on gender and age from multiple reference sources; ${ }^{1-10}$ however, references specific for elite athletes are not readily available. If long-term elevated CK in the body is as dangerous as some studies suggest, ${ }^{11}$ the role of CK in the health of elite athletes may be important.

\section{What are the new findings?}

- Current reference intervals for creatine kinase (CK) in the general population are not accurate for professional footballers.

- We recommend a new reference interval of $64.9 \mathrm{U} / \mathrm{L}$ to $1971.7 \mathrm{U} / \mathrm{L}$ for CK in male professional footballers.

- The proposed reference interval agrees with the limited published studies of football players.

It is clear that although multiple factors can influence the varying levels of CK across an entire population, ${ }^{679}$ 'naturally' higher levels can be found in elite athletes $;^{13}{ }^{12}$ however, it is not clear exactly by how much values may differ from those of the general population. Footballers in particular, due to the nature of their profession, experience excessive physical outputs throughout their sporting calendar, but it is unclear how much this work load influences their CK level.

We aimed to discover whether higher CK values were found in professional footballers than in the healthy, military population and to create an accurate reference range for healthy CK among professional footballers.

\section{METHODOLOGY \\ Subjects}

A total of 27 male subjects participated in this study, all of whom belonged to the same English League Championship football team. Twenty-five of the players are of European descent and the other two are of African descent. Seven of the 27 are black whereas the other 20 are white. The age of the participants was $24 \pm 3.7$ years $($ mean $\pm S D)$.

\section{Procedures}

Players who had not fully recovered from any form of musculoskeletal injuries were excluded from the study so that the injuries did not influence the baseline CK activity. All of the subjects trained to a high volume and intensity each week with only 1 day of total rest allocated in a week period. All 
Histogram: CK levels. 27 players

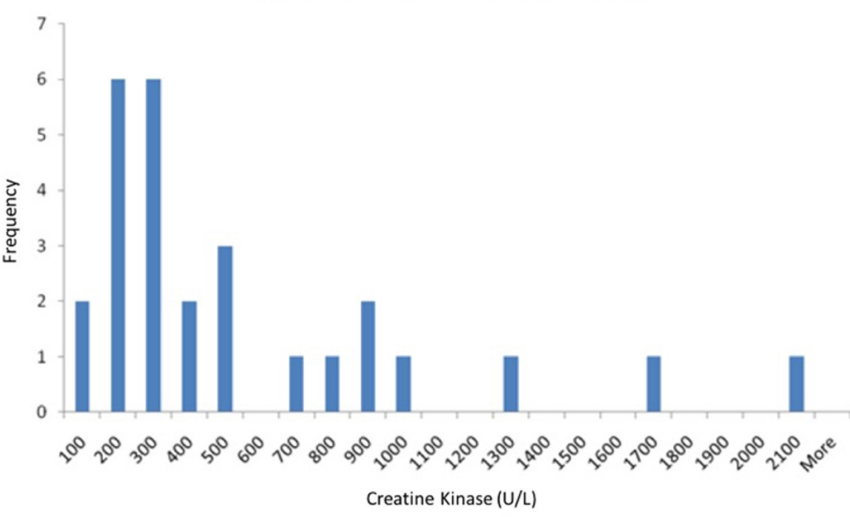

Figure 1 Histogram displaying the distribution of CK activity among a sample of 27 male professional footballers. CK, creatine kinase.

CK samples were obtained at the beginning stages of preseason training.

\section{Statistical analysis}

Data were imported into SPSS. ${ }^{1}$ The data obtained by Lev et al's (1999) study observing CK activity in Israeli army personnel was chosen as the control group because the profile of the participants in that study closely match the profile of the footballers', in terms of their gender, age and levels of physical fitness. ${ }^{5}$ The distribution of CK values in the study sample was positively skewed and not normally distributed (figure 1); therefore, a non-parametric test statistic was required.

A 'single sample Wilcoxon signed-rank test' was chosen to test the null hypothesis that the median CK value in this study sample would equal the median value $(124 \mathrm{U} / \mathrm{L})$ reported by Lev et $a l^{5}$ The level of statistical significance was stated as $\alpha=0.05$. Descriptive statistics were calculated including the mean, median, range, $95 \%$ CI for the mean and SD. Analyses were conducted using SPSS software. A $95 \%$ reference range was derived from the data based on the normal distribution. CK data were $\log$ transformed and then checked for normality with the Kolmogorov-Smirnov test.

\section{RESULTS}

One of the subjects was further analysed due to their CK activity being unusually high $(2067 \mathrm{U} / \mathrm{L})$. This subject is of black ethnicity and was also analysed separately after a series of CK readings were taken over a 5-week period.

\section{Group study}

Results are shown in table 1 for the study group of 27 male professional footballers.
Table 2 Values showing CK activity of the outlier

\begin{tabular}{lllll}
\hline Day & $\begin{array}{l}\text { Days between } \\
\text { samples }\end{array}$ & CK (U/L) & $\begin{array}{l}\text { Prior activity } \\
\text { level }\end{array}$ & $\begin{array}{l}\text { Change in } \\
\text { CK (U/L) }\end{array}$ \\
\hline 1 & 0 & 2067 & Training & N/A \\
4 & 3 & 5269 & Training & +3202 \\
6 & 2 & 3994 & Rest & -1275 \\
13 & 7 & 338 & Rest & -3656 \\
35 & 22 & 2929 & Training & +2591 \\
\hline
\end{tabular}

Marked in the table is 'training' if the subject took part in a training exercise the previous day or 'rest' if the subject rested, withholding from training. CK, creatine kinase.

\section{Hypothesis test}

Our observed sample median CK value of $284 \mathrm{U} / \mathrm{L}$ was statistically significantly higher than the value reported by Lev et al of $124 \mathrm{U} / \mathrm{L}, \mathrm{P}<0.001 .^{5}$

\section{Reference interval}

The log transformed CK values were acceptably normally distributed (Kolmogorov-Smirnov statistic $=0.123, \mathrm{df}=27$, $\mathrm{P}=0.200$ ). Based on the normal distribution the $95 \%$ reference interval was derived as $64.9 \mathrm{U} / \mathrm{L}$ to $1971.7 \mathrm{U} / \mathrm{L}$.

\section{Outlier player}

CK values for the player were recorded with his activity level. Literature exists displaying a strong link between intensive exercise and elevated CK. ${ }^{12}$ The results of the outlier are displayed in table 2.

\section{DISCUSSION}

The mean value of CK activity attained from the sample (518.6 U/L) was considerably higher than the mean value of the sample reported by Lev et al $(162.9 \mathrm{U} / \mathrm{L}){ }^{5}$ Our analyses focused on median values because for skewed data, the median better represents the middle of the data than does the mean. From figure 2, the median CK value for professional footballers $(284 \mathrm{U} / \mathrm{L})$ is far larger than that of the control group $(124 \mathrm{U} / \mathrm{L}) \quad(\mathrm{P}<0.001)$. This implies that footballers at the start of a season have a higher value of CK activity compared with the healthy military population $(\mathrm{P}<0.001)$.

A 2009 study that investigated CK activity among professional male footballers in Brazil showed similar mean values of $\mathrm{CK}(\mathrm{n}=128)(493 \pm 315 \mathrm{U} / \mathrm{L})$ when compared with this study $(518.6 \pm 496.3 \mathrm{U} / \mathrm{L})$ (values for both studies illustrated in 'mean \pm SD' format). ${ }^{13}$

The cultural diversity among the footballing study group meant that a control group similar in ethnicity to the footballers could not be found. The ethnicity of

Table 1 Descriptive statistics for the study group

\begin{tabular}{|c|c|c|c|c|c|c|}
\hline \multirow[b]{2}{*}{ Age (years $\pm S D$ ) } & \multicolumn{6}{|c|}{ Creatine kinase (U/L) } \\
\hline & Mean & Median & Range & SD & $95 \% \mathrm{Cl}$ of the mean & $95 \%$ reference interval \\
\hline $24 \pm 3.7$ & 518.6 & 284 & 76-2067 & 496.3 & 322.2 to 714.8 & 64.9 to 1971.7 \\
\hline
\end{tabular}


One-Sample Wilcoxon Signed-Rank Test

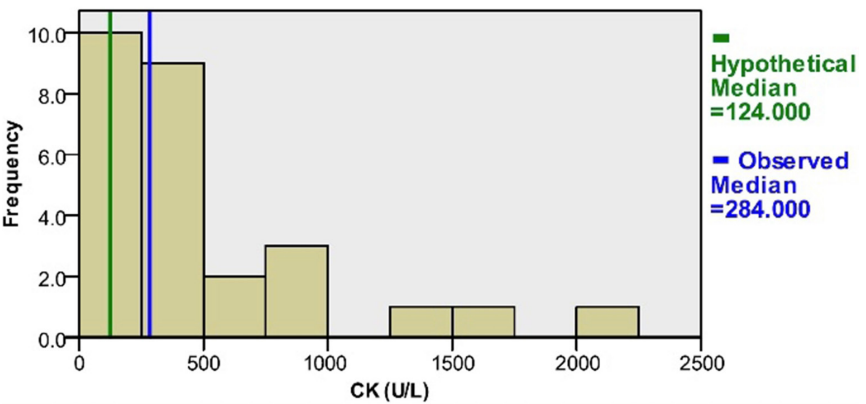

Figure 2 Histogram displaying the results from a onesample Wilcoxon signed-rank test comparing CK activity of male professional footballers with a healthy control group. $\mathrm{CK}$, creatine kinase.

the two subject groups therefore could be one of the reasons for the increased CK activity for the sample of footballers in comparison to the control group. Brewster et al confirmed that naturally higher levels of CK are found in the black population in comparison to individuals of either white or South Asian descent. ${ }^{7}$ The footballing sample included an array of different ethnicities including those of a black ethnic background. This could imply that the footballing subgroup naturally on average hold higher levels of CK in comparison to the control group which is apparent in the results.

Although it can be universally accepted that exercise increases CK activity, ${ }^{1312}$ the difference in magnitude of change in CK across sports has led to a need for sport specific reference ranges. ${ }^{4} 14$

The range of CK for the study group (76-2067 U/L) is similar to that reported in a 2007 study which presented an analysis of the CK activity among a sample of 182 male footballers, which suggested a wide reference range of $83-1492 \mathrm{U} / \mathrm{L} .{ }^{4}$ Although the two studies appear to support each other's findings, the performance level of players in the 2007 study was not reported. Our reference interval of $64.9 \mathrm{U} / \mathrm{L}$ to $1971.7 \mathrm{U} / \mathrm{L}$, derived to represent the middle $95 \%$ of CK values for professional footballers, is similar to the interval suggested by Mougios. ${ }^{4}$

The effects on the body caused by constantly elevated levels of CK are not yet fully understood. ${ }^{12}$ Relationships between elevated CK and renal failure have been highlighted as a possible link implying that professional footballers may be inadvertently forcing an unsafe amount of strain onto their kidneys due to persistently elevated levels of CK. ${ }^{15}$ However, according to study, which gave a bench-to-bench overview of rhabdomyolysis, only CK elevations above $5000 \mathrm{U} / \mathrm{L}$ are a cause for concern for the development of renal failure. ${ }^{11}$ Only one outlying individual study exceeded the CK value of $5000 \mathrm{U} / \mathrm{L}$ in this study. The highest elevation of CK was found to be $5269 \mathrm{U} / \mathrm{L}$. All medical examinations failed to explain this raised CK value.

The results suggest that whenever a rest period was taken by the outlier before a study sample was extracted, the subsequent CK value had substantially decreased.
Additionally, the longer the rest period was sustained (demonstrated as either 2 days or 7 days in this study), the greater reduction in CK activity occurred, showing that resting directly affects CK activity in the individual, and the amount that CK activity reduction is related to the duration of a rest period.

One limitation of this study is that the sample size $(n=27)$ is relatively small. However, the study conducted by Lazarim et al supports this study's findings by offering an almost identical reference range, even though the sample size was much larger $(\mathrm{n}=128) .{ }^{13}$

Another limitation for this study is the difference in ethnicity between the study and control groups. All participants in the control group originated from Israel in Asia. The study group's ethnicities originated from either Europe $(n=25)$ or from Africa $(n=2)$. Brewster $e t$ $a l$ highlighted the variance in CK activity across different ethnic subgroups. ${ }^{7}$ Therefore, in future, a control group matching the ethnicities of the study group would increase the validity of the results found when comparing the two groups to one another.

\section{CONCLUSION}

CK activity amid the professional footballing population is at a significantly higher level to those of the compared healthy population. Our data suggest that current CK reference values for the 'normal population' do not accurately represent CK values among professional footballers. We propose that the $95 \%$ reference range for CK in professional footballers be $64.9 \mathrm{U} / \mathrm{L}$ to $1971.7 \mathrm{U} / \mathrm{L}$.

Acknowledgements Cardiff City FC for allowing us to use their data.

Contributors JM, AC and LN: planning, conduction, reporting/analysis of the study. $\mathrm{JN}$ : reporting/analysis of the study.

Competing interests None declared.

Patient consent Detail has been removed from this case description/these case descriptions to ensure anonymity. The editors and reviewers have seen the detailed information available and are satisfied that the information backs up the case the authors are making.

Provenance and peer review Not commissioned; internally peer reviewed.

Open Access This is an Open Access article distributed in accordance with the Creative Commons Attribution Non Commercial (CC BY-NC 4.0) license, which permits others to distribute, remix, adapt, build upon this work non-commercially, and license their derivative works on different terms, provided the original work is properly cited and the use is non-commercial. See: http://creativecommons.org/ licenses/by-nc/4.0/

(c) Article author(s) (or their employer(s) unless otherwise stated in the text of the article) 2018. All rights reserved. No commercial use is permitted unless otherwise expressly granted.

\section{REFERENCES}

1. Mougios V. Exercise biochemistry. Champaign, IL: Human Kinetics, 2006.

2. Wu F, Beard DA. Roles of the creatine kinase system and myoglobin in maintaining energetic state in the working heart. BMC Syst Biol 2009;3:22.

3. Baird MF, Graham SM, Baker JS, et al. Creatine-kinase- and exercise-related muscle damage implications for muscle performance and recovery. J Nutr Metab 2012;2012:1-13.

4. Mougios V. Reference intervals for serum creatine kinase in athletes. Br J Sports Med 2007;41:674-8. 
5. Lev El, Tur-Kaspa I, Ashkenazy I, et al. Distribution of serum creatine kinase activity in young healthy persons. Clin Chim Acta 1999;279:107-15.

6. Gledhill RF, Van der Merwe CA, Greyling M, et al. Race-gender differences in serum creatine kinase activity: a study among South Africans. J Neurol Neurosurg Psychiatry 1988;51:301-4.

7. Brewster LM, Mairuhu G, Sturk A, et al. Distribution of creatine kinase in the general population: implications for statin therapy. Am Heart J 2007;154:655-61.

8. Kairisto V, Hänninen KP, Leino A, et al. Generation of reference values for cardiac enzymes from hospital admission laboratory data. Eur J Clin Chem Clin Biochem 1994;32:789-96.

9. Meltzer HY. Factors affecting serum creatine phosphokinase levels in the general population: the role of race, activity and age. Clinica Chimica Acta 1971;33:165-72.
10. Burtis C, Ashwood E B, et al. Tietz textbook of clinical chemistry and molecular diagnostics. st. Louis, MO: Elsevier Health Sciences, 2012.

11. Huerta-Alardín AL, Varon J, Marik PE. Bench-to-bedside review: rhabdomyolysis-an overview for clinicians. Crit Care 2005;9:158-69.

12. Brancaccio $P$, Maffulli $N$, Limongelli FM. Creatine kinase monitoring in sport medicine. Br Med Bull 2007;81-82:209-30.

13. Lazarim FL, Antunes-Neto JM, da Silva FO, et al. The upper values of plasma creatine kinase of professional soccer players during the Brazilian National Championship. J Sci Med Sport 2009;12:85-90.

14. Ehlers GG, Ball TE, Liston L. Creatine Kinase Levels are elevated during 2-A-Day practices in collegiate football players. J Athl Train 2002;37:151.

15. Brown CV, Rhee $P$, Chan $L$, et al. Preventing renal failure in patients with rhabdomyolysis: do bicarbonate and mannitol make a difference? J Trauma 2004;56:1191-6. 